\title{
Imagining the Kingdom: Mission and Theology in Early Christianity
}

\author{
N. T. Wright \\ St Mary's College, University of St Andrews, St Andrews, Fife KY16 9JU, UK \\ ntw2@st-andrews.ac.uk
}

\section{Abstract}

The four gospels rightly stand at the head of the New Testament canon. They have, however, routinely been misread or misunderstood. They tell the story of the launch of theocracy - 'the kingdom of God' - in terms of the story of Jesus; but they tell that story as (a) the narrative climax of the story of Israel (presupposing the continuous story envisaged by many second-temple Jews in terms of Daniel 9's prophecy of an extended exile), (b) the story of Israel's God returning in glory as always promised, and (c) as the rival to the powerful firstcentury narrative of Rome, as told by e.g. Livy and Virgil in terms of Rome's history reaching its climax in Augustus, the 'son of God', and his empire. The stories meet on the cross, and the purpose of the gospels is then to awaken the readers' imagination: suppose, they say, that ultimate power looks like this, not like that of Alexander the Great or Augustus. Ironically, much gospel scholarship since the rise of the critical movement has appeared eager to silence this kind of reflection; this has been due to (a) a desire to avoid continuity of narrative, (b) the implicit Epicureanism of modern western culture, with its eagerness to keep God and the world at arm's length, (c) the 'two kingdoms' theology implicit in much Lutheranism, and hence much New Testament scholarship, and (d) the triumph in modernism of what has been described by lan McGilchrist as 'left-brain' over 'right-brain' thinking. Microscopic analysis has replaced the world of intuition, metaphor, narrative and imagination, leading to readings entirely against the grain of the gospels themselves (though understandable in an academic world where the doctoral process rewards left-brain work). If we are to take the gospels' narratives seriously, however, we are projected forwards into a fresh vision of what the early church understood as its 'mission', focused on the ev̉a $\gamma \gamma \dot{\varepsilon} \lambda_{10}$ which, for the first Christians, trumped that of Caesar. Because the early church was no longer marked by the cultural symbols of ethnic Judaism, it was the freshly imagined vision of the identity of the one God that sustained them in this mission, and the ecclesial life it demanded. This was the birth of 'Christian theology'; and today's task must include the imaginative recapturing of that vision of God's kingdom, as a key element in a refreshed and gospel-grounded missiology. 
Keywords: brain, Epicureanism, Gospels, Israel's narrative, kingdom of God, left brain/right brain, missiology.

The four gospels stand magisterially at the centre of early Christianity, as they stand at the head of the canon. Despite the occasional efforts to push them out of their central position and substitute other documents, whether actually existing (such as the wrongly named Gospel of Thomas) or reconstructed (such as the hypothetical document 'Q'), the majority of scholars still believe, rightly in my view, that Matthew, Mark, Luke and John deserve their place. We might put it this way: if they had been lost for centuries, and then dug up last year in the sands of Egypt or Syria, they would be hailed as among the most extraordinary ancient documents we possess. The fact that they are well known should not blind us to their remarkable blend of page-turning narrative, vivid portraiture (especially of their central figure), historical verisimilitude and sophisticated theology.

And yet. Reversing what St Paul says about himself in 2 Corinthians 6:9, it remains the case that the gospels, though well known at one level, are unknown at another. An oversimplification, of course; but I refer to the overall drift of gospel studies, and indeed to the general perception of the four gospels in the wider church community to which the biblical studies academy remains tangentially, and sometimes uncomfortably, related. Huge strides have been made in helpful directions, not least by my predecessor but one, Professor Richard Bauckham, both in his work on the wide intended readership of the gospels and in his award-winning book on the gospels and the eyewitnesses. ${ }^{1}$ If his thesis is even half right - and I think it is at least that then all kinds of assumptions, including some of those blessed things they used to call 'the assured results of criticism', will need to be torn up and worked again from scratch. But I believe we need to go still further. Despite generations of care and attention being lavished on the gospels as wholes rather than as assemblages of parts, I am not convinced that the main message of all four gospels has been grasped - and then, having been grasped, has been reflected in the methods employed for further study. And since I shall contend here that the four gospels stand at the centre of the missionary and

${ }^{1}$ See Richard J. Bauckham (ed.), The Gospels for All Christians: Rethinking the Gospel Audiences (Grand Rapids, MI, and Cambridge: Wm. B. Eerdmans, 1998); Jesus and the Eyewitnesses: The Gospels as Eyewitness Testimony (Grand Rapids, MI, and Cambridge: Wm. B. Eerdmans, 2006). The present article is an edited version of the inaugural lecture I delivered on October 26, 2011 as Research Professor of New Testament and Early Christianity at the University of St Andrews. References to 'my predecessors' are to former holders of the chair. 
hence theological life of the early church, a failure to understand their central thrust is most likely an index of a failure to grasp several other things as well about the life and work of the first Christians.

I don't want to be thought alarmist. Fine work in many directions has been done on the gospels, a generation ago by another predecessor, Matthew Black of blessed memory. And of course Robin Wilson, of more recent memory, contributed much to our understanding of the hinterland of early Christianity within which the gospels and their early reception must be understood. But there comes a time in every discipline when one has to take a deep breath, stand back a bit and say, 'Well and good; but perhaps we're still missing something'. I think this is one of those moments. And, at such times, what is required is not simply more attention to detail, vital and central though that remains. What is required is precisely imagination: a willingness to think beyond the fence, to ask questions which have hitherto been screened out. And, to complete the list of predecessors over the last fifty years, Markus Bockmuehl published a remarkable book, Seeing the Word, in which he offered an eloquent and wide-ranging plea for just such an imaginative leap, a reassessment of the tasks and methods of the whole discipline. ${ }^{2}$ That is the kind of exercise to which I now want to give attention.

I have three basic things to say. First, I shall propose a fresh thesis about the gospels, stressing the invitation they offered to their first readers to imagine a new state of affairs being launched into the world, a state of affairs for which the natural shorthand was 'the kingdom of God'. This might seem rather obvious, but in fact the history of gospel scholarship for at least the last century has included many avoidance mechanisms, drawing attention away from the uncomfortable claim which the gospels are in fact making. This will lead to the second section, in which I want to pull back and survey the wider intellectual and cultural climate in which the discipline of 'New Testament Studies' was born and nurtured, and suggest that the failure to grasp the central message of the gospels flows directly from the post-Enlightenment agendas which have dominated the discipline. It is important, though, to stress both that my proposal is neither for a return to a pre-Enlightenment or anti-historical method, nor for a too-enthusiastic embrace of postmodern modes of operation, and that I regard a good deal of what has passed for 'conservative' or 'orthodox' responses to the mainstream Enlightenment agenda as sharing in, rather than solving, the underlying problems. This will send us back, third, to the gospels and the other New Testament writings with some fresh possibilities before us. I want to stress what seem to me the central grounding

2 Markus Bockmuehl, Seeing the Word: Refocusing New Testament Study (Grand Rapids, MI: Baker Academic 2006). 
features of early Christian mission, and the way in which what came to be called 'Christian theology' grew out of that, not as a detached intellectual exercise but as the necessary anchoring of the central Christian symbol.

\section{How God became king: the story of the gospels}

My proposal about the gospels is that they all, in their rather different ways, tell the story of Jesus of Nazareth as the story of how God became king. They all, in other words, announce the launch of what can only be called a 'theocracy'. And my contention here is that, by and large, research into the gospels has for the last hundred or more years managed not to notice this, to screen out the claim which would have been obvious in the first century and which sustained the early church in its life and mission. ${ }^{3}$

The word 'theocracy', of course, sends shivers down many spines today. In our current climate, with the uneasy stand-off between secularism and fundamentalism, the idea of a 'theocracy' sounds uncomfortably like a return to what people vaguely imagine as the situation of the Middle Ages, with popes, bishops and priests ordering everyone about - or, indeed, to the forms of theocracy envisaged and sometimes even implemented in other religions today. (When I was lecturing in Ireland recently, someone asked me to comment on the fact that only two countries in the world have clergy sitting as of right in the upper chamber of Parliament: the UK on the one hand and Iran on the other.) And most modern westerners, not least in our great universities, react very strongly against any type of larger oversight, rightly valuing their freedom both of action and of thought. Theocracy is what we thought we'd got rid of, not something we wanted to discover in some of the Western tradition's most central texts.

But 'theocracy', in a sense yet to be defined, is of course what is meant by 'the kingdom of God', which the synoptic gospels highlight at the central motif of Jesus' public announcements and which the fourth gospel presupposes as his central theme. ${ }^{4}$ We know from Josephus that the revolutionaries, in the last century before the disastrous Roman-Jewish war, took as their battle-cry the slogan 'no king but God!' ${ }^{5}$ Presumably they thought they knew how God would exercise that kingly rule; presumably they imagined that they themselves might act in some way as divine agents. But

3 Cf. N. T. Wright, How God Became King (San Francisco and London: HarperOne and SPCK, 2012).

4 The first time we meet the expression in John (3:3), it seems to be assumed that this is what Jesus is all about.

${ }^{5}$ Josephus, Ant. 18.23; see the discussion in N. T. Wright, The New Testament and the People of God (London and Minneapolis: SPCK and Fortress Press, 1992), pp. 302-7. 
that 'God's kingdom' denoted the long-awaited rule of Israel's God on earth as in heaven there should be no doubt. The widespread assumption today that 'the kingdom of God' denotes another realm altogether, for instance that of the 'heaven' to which God's people might hope to go after their death, was not on the first-century agenda. When Jesus spoke about God's kingdom, and taught his followers to pray that it would arrive 'on earth as in heaven', he was right in the middle of first-century Jewish theocratic aspirations.

So when the gospels tell the story of Jesus, they do so (to repeat) as the story of 'how God became king'. It wasn't, for them, just an aspiration; it was an accomplishment. We can see this in three narratival strands which work together in all four gospels (though not, interestingly, in any of the noncanonical gnostic materials). As throughout this article, I here summarise material which could be set out in considerably more detail.

The three strands in question come in addition to, not in competition with, the two more normally observed. Gone are the days when people could confidently affirm that the gospels were in no sense 'biographies' of Jesus. Several studies have indicated the reverse: when placed alongside Graeco-Roman bioi, the four canonical gospels clearly belong in something like the same genre. ${ }^{6}$ Nor is there any problem in continuing to affirm that the gospels tell the story of Jesus as the story of the launching of the movement which, perhaps anachronistically, we refer to as 'the church'. How precisely the gospels reflect early Christian faith and life is another matter, but that they do so is not in question. The gospels are, in a perfectly proper sense, 'biographies'; they are also foundation documents for Jesus' first followers. But the three further interlocking dimensions we must now explore are key elements which have, all too often, been missing from the discussion.

The first of these missing dimensions is that the four canonical gospels tell the story of Jesus as the continuation and climax of the ancient story of Israel. To say this is more than to say that the gospels portray Jesus as the fulfilment of ancient prophecy. That is obvious. It is the kind of fulfilment which matters here. The gospels give every sign - admittedly in four different ways - that they belong to that feature of the Jewish world of the day in which the longer story of Israel was being told in search of an ending, and that they are writing in order to provide such an ending. What matters - and what, I think, goes radically against the grain of Western thought for many centuries is the idea of narrative continuity. Not just 'narrative' as such; that might lead simply to a repeated pattern, which we naturally find as well, for instance in the strong sense of a 'new exodus', the fresh and final repetition of ancient

${ }^{6}$ See particularly Richard J. Burridge, What are the Gospels? A Comparison with Graeco-Roman Biography, 2nd edn (Grand Rapids, MI, and Cambridge: Wm. B. Eerdmans, 2004). 
Israel's greatest story. That is important, but it points beyond itself to the belief, which we can track in many Jewish texts of the time, that all these repeated patterns were part of a larger sequence that was going somewhere. History might be in some sense cyclic, but in a more important sense the cycles contributed to a forward, linear movement.

Thus, for instance, the book we call Pseudo-Philo tells the ancient story of Israel and breaks off at the point where David is about to become king. Its recounting of the tales of the Judges seems to be designed as a model for militant messianic movements in the writer's own day. Similarly, the book of Wisdom recounts the story of the Exodus, not simply as a great historic moment in Israel's ancient past, but as the model for the new and decisive act of judgement which Israel's God is about to perform, condemning the wicked and vindicating his wise and righteous sufferers. At that level, despite the radical difference of genre, this is much the same as what we find in 4 Ezra and 2 Baruch, who look back to the horrible events of 586 BC as a kind of model for what they have now experienced in $\mathrm{AD} 70$, and retell the ancient story as a way of leading the eye up to the great messianic deliverance which is about to burst upon the world, with (in 4 Ezra's vision) the messianic lion triumphing over the pagan eagle. ${ }^{7}$

All of these, in their different ways, look back to the scriptures, and particularly the book of Daniel, with its intriguing combination of the genres of wisdom and apocalyptic. In fact, the storytelling at which we have just glanced belongs within a much larger movement of thought in which Daniel 9 in particular became seminal. In Daniel 9 the prophet asks how long the exile is going to be: will it not, as Jeremiah prophesied, last for seventy years? Back comes the answer: not seventy years, but 'seventy weeks of years'; that is, seventy times seven. ${ }^{8}$ There are important echoes here of the Jubilee theme from Leviticus 25, but for our purposes the point is that this 490 years, predicted in Daniel 9, haunted the minds of devout Jews in the centuries immediately before and after the time of Jesus. There is plenty of evidence to indicate that people within various movements were calculating, as best they could, when that time would be up, and when the long-awaited deliverance from pagan domination would therefore occur. Their answers varied wildly. The Essenes, it appears, pinned their hopes on the climax coming around the time when Herod the Great died. Some Rabbis, however, did their sums quite differently (it all depends, of course, where you begin the sequence), so that when Akiba hailed Simeon ben Kosiba as Messiah in AD 132 some of his colleagues opposed him, not so much because ben Kosiba was not

74 Ezra $11: 1-12: 39$.

${ }^{8}$ Dan 9:2 (cf. Jer 25:11; 29:10; Zech 1:12; 7:5; 2 Chron 36:21; 1 Esd 1:58); 9:24. 
a suitable candidate but because, according to their calculations, the Son of David was not due for at least another century. ${ }^{9}$

All this, interesting though it is, simply points to the widespread phenomenon which is, I suggest, the presupposition for the story the gospels tell in the way they tell it: that Israel's history, under the guidance of a strange and often opaque divine providence, had not come to a standstill, but was moving forwards towards its appointed goal. The story has many twists and turns, and many flashbacks and indeed flash-forwards, advance hints of what is to come. But it is a single storyline, and it is awaiting its proper and fitting fulfilment. My first point, then, is that all four gospels, in their different ways, are written so as to say that the story of the public career and fate of Jesus of Nazareth provides that proper and fitting, if highly surprising and subversive, fulfilment. Jesus is not, for the evangelists, simply the antitype of the various types such as Moses, or David, or the Passover lamb. He is the point at which the millennia-long narrative has reached its goal. Matthew makes the point, graphically, with his introductory genealogy. Mark does it with his opening quotations from Malachi and Isaiah; Luke, by telling the story of John the Baptist as a reprise of the story of Samuel. (They do it in many other ways, too, but these stand out.) John goes right back to the beginning, to the opening of Genesis, and structures his gospel so as to say that in Jesus not only the story of Israel but the story of all creation is reaching its decisive goal. And in all four gospels there are clear echoes and references back, in a variety of ways and contexts, to the various prophecies of Daniel, including those of chapter 9.

It is in Daniel, of course, that we find the strongest statement of what the climax will be, when it comes: it will be the arrival of God's own kingdom, his sovereign rule, trumping the rule of all pagan powers. And it is to Daniel that we should look to find the text which, according to Josephus (echoed at this point by Suetonius), most incited Jews to rebel against Rome: the text according to which a world ruler would, at that time, arise from Judaea. ${ }^{10}$ Josephus and Suetonius, of course, refer this to Vespasian, called back from the campaign against Jerusalem to become Emperor in Rome. The four gospels, clearly, have another candidate in mind. And, for that matter, a different sort of kingdom. But to that we shall return.

9 On all this, see esp. Roger T. Beckwith, Calendar and Chronology, Jewish and Christian: Biblical, Intertestamental and Patristic Studies (Leiden: E. J. Brill, 1996).

${ }^{10}$ Josephus, War 6.312-15; cf. Suetonius, Vespasian 4, and also Tacitus, Histories 5.13. See the discussion in Wright, The New Testament and the People of God, pp. 312-13. Compare Josephus, Ant. 10.267, where Josephus highlights, as the distinctive feature of Daniel, that his prophecies had a specific chronological reference. 
Much more could be said about the way in which the four gospels tell the story of Jesus as the climax of the continuous story of Israel, with the kingdom of God arriving at that climax. But I move rapidly to the second point, which is that the gospels tell this story as the story of Israel's God. Here we must take a step back once more, because it is not as well known as it ought to be that in the world of Second-Temple Judaism there was a strong sense, not just that Israel's fortunes needed to change, but that Israel's God needed to come back to his people, to the temple. Ezekiel had described the divine glory leaving Jerusalem, and had prophesied that it would return to a rebuilt temple, but nobody ever said they'd seen it happen. There is no scene anywhere in the literature of the period to correspond to Exodus 40, where the divine glory fills the newly constructed tabernacle, or 1 Kings 8, where the same thing happens to Solomon's Temple. There is no sudden appearance, as was granted to the prophet Isaiah. Plenty of texts say that it will happen (I think, obviously, of Isaiah 40 and 52; of Zechariah and Malachi), but none indicate that it already has. ${ }^{11}$

Here the four evangelists are quite explicit. John is perhaps the most obvious: 'the word became flesh', he says (1:14), 'and tabernacled, pitched his tent, in our midst; and we beheld his glory'. In case we missed the point, John rubs it in again and again by his constant positioning of Jesus in relation to, or in the place of, the Temple (e.g. 2:21). Mark, outwardly so different to John, hits exactly the same note with his opening quotations from Isaiah and Malachi. Both passages concern the return of the divine glory, and the messenger who will prepare the way for it. Mark leaves us in no doubt that he thinks that this has now happened, in and through Jesus. Matthew and Luke in their own ways get at the same point, Matthew not least with the Emmanuel promise (1:23 and 28:20) and Luke not least through the terrifying scene in chapter 19 where Jesus, arriving in Jerusalem, tells the story about the king who comes back at last only to find a disobedient servant, and then announces Jerusalem's imminent destruction on the grounds $(19: 44)$ that 'you did not know the moment when God was visiting you' (Tòv kaıpòv

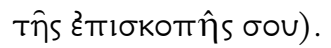

This rather simple observation, clearly, puts the cat among several of the older critical pigeons. I grew up in a scholarly world where it was taken for granted that while John had a high (and most probably Greek) christology, the synoptics had a low (quite possibly Jewish) one. That only shows the extent to which people were asking the wrong question. Once we think into the world of first-century Jewish narrative, a very different picture emerges.

11 I survey the evidence in N. T. Wright, Jesus and the Victory of God (London and Minneapolis: SPCK and Fortress Press, 1996), pp. 615-24. 
To the old sneer that Jesus talked about God but the early church talked about Jesus, we may reply that Jesus did indeed talk about God and God's kingdom in order to explain what he himself was doing and would accomplish.

It is this picture, third, which confronts - as Israel's stories normally did confront - the power of pagan empire. The four gospels, again in their very different ways, are all written to tell the story of Jesus as the story of Israel, and the story of Israel's God, reaching their proper climax, so as thereby to tell the story of how Israel's God becomes king of the whole world. This is the clue to the mission, and the missionary theology, of the early church, to which I shall return.

Think for a moment of the narrative which had burst upon the world around the time that Jesus of Nazareth was born. The intellectual coup d'état which Augustus accomplished through his court poets and historians was every bit as stunning as the political coup he achieved in the double civil war which followed the assassination of his adoptive father, Julius Caesar. Everybody in Rome knew that Augustus' attaining of supreme and unchallengeable power meant the overthrow of a centuries-long tradition of fierce republicanism (Augustus, of course, insisted that he had merely restored the republic, but nobody was fooled). But for Livy to tell the history of Rome through the long years of the Republic and climaxing with the rule of Augustus, with whom he had a lasting friendship, was a remarkable achievement. Scholars differ on the extent to which Livy himself believed that the rule of Augustus was an unqualified good thing, and Tacitus records (Annals 4.34) that in one of the later, and sadly lost, books of his great work Livy felt able to praise the conspirators Brutus and Cassius. But he knew which side his bread was buttered on, as is evidenced for instance by his distorting of key political details to suit the new regime. ${ }^{12}$ And the greatest writer to tell the long story of Rome as a history leading the eye up to Augustus was of course Virgil. His early Eclogues refer to the turbulent events of the civil war, and include the mysterious fourth, hailing the birth of a child who will usher in the golden age. Virgil read the Georgics to Augustus in person after his victory at Actium in $31 \mathrm{BC}$; and he was regularly in the company of Augustus during the years in which he composed the Aeneid itself, the greatest poem of the period. Here there is, as is well known, a 'strong narrative teleology', ${ }^{13}$ invoking 'Fate' as the force which will lead Aeneas to found Rome and Rome to produce, eventually, the wonderful new empire

12 E.g. 4.20, where Livy suggests that Cornelius Cossus was consul, not merely a military tribune, when celebrating his single-handed victory over an enemy commander four centuries earlier, thus supporting Augustus' jealous retaining of military glory for himself in his own day.

13 OCD 1606 (D. P. Fowler and P. G. Fowler). 
of Augustus. Already in the first book the scene is set, with Jupiter himself prophesying to the world, back then in the time of Aeneas, that from his noble line there will be born 'a Trojan Caesar, who shall extend his empire to the ocean, his glory to the stars' (1.286-7). His empire will be lavishly prosperous, and will bring peace to the world (1.289-96). Indeed, Aeneas himself is seen as a type of the coming Augustus, an indication that here, too, typology can flourish within an overall grand narrative. I am not aware of anyone before Augustus causing the story of his own accession to power to be told as the climax of a much longer narrative. ${ }^{14}$

It is only when the first of my three points is fully grasped (which, as I've suggested, is not normally the case) that the breathtaking phenomenon emerges. There is no sign that the Romans are borrowing from Jewish tradition the idea of a centuries-old history climaxing in a surprising but victorious, prosperous and peace-bringing reign. Nor is there any suggestion that Matthew, Mark, Luke or John had read Livy or Virgil. ${ }^{15}$ But their story of Jesus as bringing the long history of Israel to an unexpected climax was not only a remarkable parallel to the great Roman narrative, which Augustus and his successors were busily reinforcing in statues, coins and other symbolic artefacts. It was bound to be set on a collision course. The Jews, too, had cherished a prophecy about a coming king whose peaceful rule would extend from one sea to the other, from the River to the ends of the earth. ${ }^{16}$ And the four evangelists declare that this king has arrived, and that his name is Jesus. It is not surprising - to anticipate a later point - that we find the early church accused, in northern Greece which was such key terrain for the early Empire, of behaving contrary to the dogmas of Caesar, and saying that there

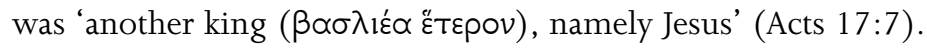

Rome is, of course, scarcely mentioned in the four gospels, yet for those with first-century ears attuned its presence is everywhere presupposed. John's great climactic scene of Jesus and Pilate - the kingdom of God against the kingdom of Caesar, challenging one another's visions of kingdom, truth and power - shows where, for him, the story was heading all along. ${ }^{17}$ Luke stages the birth of Jesus carefully in relation to the decree of Caesar Augustus, and his second volume ends with Paul in Rome announcing God as king and Jesus as lord, 'openly and unhindered'. ${ }^{18}$ Matthew and Mark draw heavily on Daniel

${ }^{14}$ Cf. the full exposition in David R. Wallace, The Gospel of God: Romans as Paul's Aeneid (Eugene, OR: Pickwick Publications, 2008), part I.

15 Though Wallace makes a case for thinking that Virgil, at least, was widely known across the empire by the middle of the century.

16 E.g. Ps 72:8; 89:25; Zech 9:10.

17 John 18:28-19:16.

18 Luke 2:1; Acts 28:31. 
7, the passage above all where God's kingdom confronts and overthrows the kingdoms of the world, seen as a succession of four increasingly horrible monsters. There is no doubt, in the first century, that the fourth monster would have meant Rome. And it is possible that Mark himself may have deliberately framed his gospel with strong hints that in Jesus an empire was coming to birth of a completely different character to that of Caesar. A recent article contrasts the dove which descended on Jesus at his baptism with the Roman eagle, appearing as an omen to further the cause of Augustus or his successors. ${ }^{19}$ Furthermore, an increasingly common interpretation of Jesus' triumphal entry into Jerusalem is to see that event not only as the staged fulfilment of Zechariah 9 but also as a deliberate parody of the regular entry into Jerusalem of Pontius Pilate, on horseback surrounded by soldiers, coming from his quarters in Caesarea. ${ }^{20}$ Whether or not that is correct, we should certainly see the muttered remark of the centurion (15:39) at the foot of the cross as vital. Mark hopes that his Roman readers will come to share this astonishing viewpoint. In a world where Caesar, unambiguously, was hailed as 'son of God', the centurion looks at the dead Jesus and transfers the title to him.

The cross, in fact, is for the evangelists the point where all the lines meet: the lines that run forward from Abraham, David and the exile; from 2 Samuel 7, Psalm 2 and Psalm 72; from Exodus 40 to 1 Kings 8 and Ezekiel 43; and, above all, from Isaiah 40-55 all the way into the mindset of Jesus himself and the interpretative work of the writers. The story told by all four gospels is the story of 'how God became King': not by the usual means of military revolution, but by the inauguration of sovereignty during Jesus' public career, and the strange but decisive victory on the cross itself. All four evangelists report that Jesus was executed with the words 'king of the Jews' over his head; and, as they all knew though many scholars have long forgotten, the ancient Jewish dream was that the king of the Jews would be king of the world. Of course: if Israel's God was the creator of the world, one would expect nothing less. And what the four evangelists are asking their readers to

19 Michael Peppard, 'The Eagle and the Dove: Roman Imperial Sonship and the Baptism of Jesus (Mark 1.9-11)', New Testament Studies 56/4 (2010), pp. 431-51.

20 Though not directly described in ancient sources, this seems to have become a common theme in sermons and popular addresses: http://www.christianity.org.uk/ index.php/showdown.php. An earlier scholarly study of the possibilities is Brent Kinman, 'Jesus' “Triumphal Entry” in the Light of Pilate's', New Testament Studies 40/3 (1994), pp. 442-8; his proposal is based on the known behaviour of Roman governors elsewhere rather than on direct evidence about Pilate's own coming to Jerusalem. However, the suggestion is certainly very plausible. 
do, as they ponder this strange multi-layered narrative, is precisely to imagine: to imagine that this, rather than something else, is what it would look like when God became king. Along with music and the visual arts, narrative is a primary human means of stimulating the imagination. This, I suggest, is precisely what the four gospels are aiming to do.

These are the themes which I see prominently in the gospels but not so prominently in contemporary scholarship. Indeed, one might observe that much of the effort expended on the gospels over the last hundred years and more has been directed not towards grappling with these issues, but precisely towards holding them at bay. Narrative and imagination have been at a discount; the mechanical study of dismembered fragments has been the rule. Most of the much-vaunted 'methods' proposed in gospel scholarship have been generated from within a world where all that I have just said was ignored. Such methods are not neutral; they reflect the underlying assumptions of their makers, and I am suggesting that those underlying assumptions were deeply flawed. But why should this have been so? To try to understand that I turn to the second main section of my article.

\section{Avoiding the kingdom: the story of biblical scholarship}

Histories of biblical scholarship cover many issues, and it is important that in engaging with our predecessors as historically minded critics of the New Testament we contextualise them, as we must ourselves, in the climate of thought in which they lived. An obvious example, related directly to what I just said about dismembered fragments, is the great German Rudolf Bultmann. He was himself keenly aware of his own presuppositions, though many of his followers, not least in Britain and America, were inclined to treat his work as simply the objective results of neutral scholarship. Anything but: he was writing his major work on the gospels at a time when, after the First World War and the demise of the Kaiser and other 'great men', Germany was trying to become simply a 'community', a Gemeinde, in the Weimar Republic. What did Bultmann do? He wrote about the gospels as the collections of stories which die Gemeinde, the 'community', told amongst themselves to sustain their present faith, not at all intending reference to a recently departed 'great man', except for the sheer fact of his crucifixion. No thought of 'kingdom' there in any sense that a first-century Jew might recognise.

But that observation is simply the tip of the iceberg. So, too, is the necessary warning issued a generation ago by Hans Frei, that for much of the last two centuries narrative itself has been 'eclipsed' in biblical scholarship, which regarded stories as secondary and looked instead for nuggets of doctrinal and 
ethical teaching. ${ }^{21}$ (We might compare the recent anti-Bible put out by the philosopher A. C. Grayling which, despite its attempt to parody the actual Bible, consists of no narrative at all but only wise sayings and advice. ${ }^{22}$ ) But, again, one has to go further back and ask why. This is a question which demands a multi-volume answer, and all I can do here is to put two or three items on the table for further discussion as we seek to understand how and why the discipline has gone in the directions it has. I shall, of course, greatly oversimplify many complex issues. My aim is to stimulate the disciplined imagination, not here to nail down exact arguments.

First, ever since the Renaissance the implicit narrative of Western culture has been tripartite. There is the good early period; then there is the bad or boring middle period; then there is the sudden reawakening, the shining of a great light, and we can retrieve the good early period - or some of it, anyway in a newly formed culture or worldview. Thus the Renaissance itself, fed up with what was seen as the stodgy and unimaginative categories of the late Middle Ages, saw itself as a break with the immediate past and a retrieval of an earlier golden age. The Reformation, in its turn, went exactly the same route, returning not to the Renaissance's pagan sources but to the Bible and the early fathers, largely agreeing about the dark middle period from which one needed a clean break. The Enlightenment, some of whose seeds were sown in both the Renaissance and the Reformation, has constantly tended to portray everything before it as ignorant superstition, hailing modern science and technology as the signs of the brave new world which enable us to draw an even thicker line between ourselves and our predecessors, retrieving only those bits and pieces of earlier wisdom which may commend themselves from time to time. One way or another, though, all these great movements have contained an implicit (and often explicit) narrative in which precisely what one does not want is continuity. Within Protestantism in particular and until fairly recently most of the running in biblical scholarship was made by Protestants of one stripe or another - the sense of a major break in the narrative is deeply important. Anything else might signal, at least by implication, that the Catholics had been right all along, even though ostensibly the story being told would have been about the first century rather than the sixteenth. There has, then, been deep visceral resistance to any idea of a continuous narrative, and this itself has greatly impeded a recognition of what the gospels were actually doing.

21 See Hans W. Frei, The Eclipse of Biblical Narrative: A Study in Eighteenth and Nineteenth Century Hermeneutics (New Haven, CT: Yale University Press, 1974).

22 A. C. Grayling, The Good Book: A Secular Bible (London: Bloomsbury, 2011). See the telling review by David Martin, in The Times Literary Supplement, 3 June 2011, pp. 25-6. 
Second, however, the movement of thought from the Renaissance to the Enlightenment can be characterised especially by the major revival of Epicureanism. Ever since Poggio Bracciolini rediscovered Lucretius' great poem De Rerum Natura in an obscure European monastery in 1417 - exactly a century before Luther's supposed rediscovery of Paul's theology led him to nail his theses to the Wittenberg door - the great alternative philosophy of the first century (alternative, that is, to the otherwise dominant Stoicism) had been making its way in European circles. ${ }^{23}$ It came to its full flowering with the thinkers of the Enlightenment, taking in such seminal figures as Giordani Bruno, Montaigne, Galileo, Bacon, Hobbes, Newton, Hume and, not least, Thomas Jefferson, who famously proclaimed 'I am an Epicurean'. (That claim has to be taken seriously, despite Jefferson's attempts to have his cake and eat it by also noting his admiration for Epictetus, a first-century Stoic, and of course for Jesus himself; the latter two were subject to Jefferson's own rather heavy-handed attempts to decontextualise them and present the cleaned-up results in a way which sustained his other agendas rather than undermining them, as left to themselves they might have done.) The point, of course, is that in Epicurean philosophy, over against the confused and often frightening paganism of the ancient world and then the confused and often frightening religion of the Middle Ages, the gods are removed far away, off to a distant heaven from which they don't even bother to look down, let alone to get involved in the affairs of the present world. The world itself, according to the first-century Darwinism of Lucretius, consists of atoms, and the objects made up of them, moving under their own steam, without divine intervention, developing and transforming themselves according to their own energy, their innate 'swerve' (clinamen, a crucial Epicurean term), and the survival of the fittest. Human society, likewise, should be able to order itself from within, needing no divine intervention whether through kings or priests or anybody else. The modern movement of liberal democracy is thus the twin sister of modern atheistic science, both sharing Lucretius as the primary ancestor and the Enlightenment philosophers as the immediate parents. Biblical scholarship as we know it today was born in a world where the gods had been banished far away, a world in which humans and their societies moved under their own steam. ${ }^{24}$

It is important to stress this matrix, because the majority of Westerners today simply do not realise either that they are Epicureans by default or

23 See now esp. Stephen Greenblatt, The Swerve: How the Renaissance Began (London: Bodley Head, 2011).

24 On Epicureanism as a key element in modern Western thought, cf. esp. Catherine Wilson, Epicureanism at the Origins of Modernity (Oxford: Oxford University Press, 2008). 
that Epicureanism always was only one philosophy among others. As a young theologian I was taught, quite fiercely, that the Enlightenment had opened up a new saeculum (as indeed the American dollar bill declares to this day), and that we could not think of challenging it. Everything earlier was therefore relativised; just as George Washington had suggested that the world prior to the eighteenth century had been full of superstition, so modernist theologians insisted that we simply could not, today, share 'ancient worldviews'. That, of course, was the grand narrative against which postmodernity has protested so strongly, shaking the old Enlightenment certainties to the core. But people usually do not realise that the Epicurean stance of separating God or the gods from the world was always simply one option among others, philosophically speaking; that it was always an unstable option (since the gods always tended to sneak back in by other means, as in the Romantic movement's pantheistic answer to Enlightenment rationalism); that it was always a costly option, easier to embrace if you were rich enough to enjoy the Epicurean lifestyle. ${ }^{25}$ But the most important point is that this unstable and costly option was always going to be a very bad framework for understanding the Jewish traditions, especially the New Testament itself.

Now of course, as a historian, I believe that people with all kinds of different worldviews can and should study the evidence of the past and offer what interpretations they can of it, and particularly - the heart of good history - what made people tick. As the great contemporary historian, Asa Briggs, has written in his recent account of his time at Bletchley Park, what made young historians such good codebreakers is that they were "well read, drawn to lateral thinking, and taught to get inside the mind of people totally different from themselves'. ${ }^{26}$

But there's the point. To use the anthropologist's jargon, historians of whatever background and context ought to have a stab at offering an etic account of the societies they are studying, that is, an outsider's fair analysis of the phenomena before them. But, as with anthropology, so with history, the pressure is there to provide what purports to be an emic account - an account of how the people themselves actually thought - but which turns out to be the etic one in disguise. And when, in the case of Enlightenment historiography, the etic account was offered from within Epicurean principles, the chance of

25 Not, except in some debased forms (cf. e.g. Peter Gay, The Enlightenment: An Interpretation. vol. 1, The Rise of Modern Paganism (New York: Alfred A. Knopf, 1966), pp. 306-8), in the sense of 'hedonism', but in the classical sense of retirement to a quiet and peaceful life.

26 Asa Briggs, Secret Days: Code-Breaking in Bletchley Park (London: Frontline Books, 2011), p. 78. 
getting anywhere near the emic account that first-century Jews (including the early Christians) might have offered was severely reduced. In fact, within the Epicurean worldview Judaism was reduced, first, to being a 'religion' (the word 'religion' having been already severely redefined to reflect Epicurean principles, meaning now 'that which humans do with their solitude'), and then to being the wrong sort of religion (since the Jews persisted, perversely from the Epicurean point of view, in believing that the real world of creation, and human actions within it, actually mattered as part of the whole).

Those who embraced the Enlightenment but sought still to be good Christians thus portrayed themselves in a different light. Martin Luther's Protestantism, in which Paul rose and smote the wicked Judaisers, came to birth in a new form, as Christianity had to become un-Jewish in order to hold up its head in European culture. I'm talking here about the 1830s, not yet the 1930s (and leaving the 1530s to fend for themselves), but the point should still be clear. Religion and ordinary life had to be kept as far apart as possible. That was part, it seemed, of the point of justification by faith. The French went all the way with the Enlightenment agenda, and tried to wipe out religion entirely - an attempt which is still in progress today with the banning of Muslim headscarves. The Americans compromised, and insisted simply on a rigid separation of church and state. The English, as usual, looked this way and that and muddled along. As a newcomer to Scotland, I had better not try to describe what happened north of Berwick-upon-Tweed, though the simultaneous influence of John Knox and David Hume has no doubt left an interesting legacy. As for Ireland, I am reminded of the remark of my good friend the Irish American biblical scholar, Dominic Crossan, who has said more than once in my hearing that the Irish never really got the Enlightenment, but they got the British instead, which they found most enlightening in other ways. But my point is this: Epicureanism, and its social and political outworkings, may or may not be the best way for us today to organise our world. I would argue not, but that's not the point. But it is certainly not a good way for us to understand the world of the early Christians.

The discipline of New Testament Studies has reflected this, on both sides of various great debates. The fateful Enlightenment split between the gods and the world has generated a new meaning for words like 'natural' and 'supernatural'. It is now widely believed by would-be Christian apologists that part of the task is to defend something called 'the supernatural', in which a normally distant divinity invades the 'natural' world to perform 'miracles' or even, in the Christian story, to become human. But this merely reinscribes and perpetuates the Epicureanism which still serves as the framework for the discussion. Thus, in the study of the gospels, so-called 'liberals' have done their best to offer would-be historical accounts in which Jesus was 
'really' a Jewish revolutionary or teacher or apocalyptic prophet (the notion of 'apocalyptic' itself, by the way, has suffered radically through this process, but that's another story), while the so-called 'conservatives' have done their best to offer a historical account in which Jesus really was a 'supernatural' being who really did do miracles and rise from the dead.

Since in my own work I have done my best to counter some of the revisionist proposals it might be easy to suppose I was simply taking the latter path. Rather, I want to insist that to understand the first Christians we must understand the radical difference between the ancient Jewish worldview and the ancient Epicurean worldview (remembering not least that one of the sharpest insults a Rabbi could offer to heretics was to call them apikorsim, Epicureans). In the ancient Jewish worldview, the one God was not removed from the world, but was mysteriously present and active within it, at least in theory, so that if he remained absent, as in the Second-Temple period, there was precisely a sense of that absence. And the modes of his presence and activity were concentrated on the major Jewish symbols: Temple, Torah, land, family, and not least the great narrative which was continuing and would be fulfilled even though it might have seemed for the moment, like a submerged stream, to be running underground. This was the air Jesus and his first followers breathed. The task of describing, from an emic viewpoint, the mindset and motivation of the earliest Christians is thus one for which the Epicurean worldview is singularly badly suited. And to the extent that the movement of nineteenth-century biblical scholarship was done from within that Enlightenment framework, in its various forms owing much to Kant, Hegel and later Feuerbach, it was bound to misunderstand and misrepresent what those earliest Christians were about. And since some of the nineteenthcentury proposals are still alive and well, as the sheer inertia of a complex discipline keeps them alive long after their sell-by date, we still find ourselves facing categories like 'Jewish Christian' and 'Gentile Christian', like 'Early Catholicism' and 'Enthusiasm', which actually demand such radical overhaul that it might be better to draw a line, in our turn, across the false would-be Heilsgeschichte of triumphalist scholarship, and try to start again.

There is another element to all this which I just mention before turning to my final point about the cultural context of modern biblical scholarship. Much of the work I have described has been done within the Lutheran tradition. But, for all its strengths, the Lutheran world has long embraced a 'two kingdoms' theology in which God and Caesar simply won't mix. And that, when coupled with the Enlightenment's Epicureanism, has produced several generations of scholarship in which, for instance, it is simply off limits to imagine that Paul might have regarded Jesus as Israel's Messiah, with all the overtones of world sovereignty which that word carried. The 
general view of scholarship has colluded with the general view of popular Western Christianity, that the purpose of the whole thing is 'to go to heaven when you die', rather than discerning, 'imagining' shall we say, the kingdom of God on earth as in heaven and working for that end. Of course, liberation theology and its various exegetical offshoots have tried to present a rival view. But, as with the so-called 'conservative' reaction, this has often simply maintained the split world of the Enlightenment, proposing (for instance) that Paul was 'really' a politician and therefore not really a theologian after all. ${ }^{27}$ Similar things might be said about some of the work, important in its own way, which has gone under the umbrella of 'sociology' or 'anthropology'. From the post-Enlightenment standpoint, this appears to be on the 'worldly' side of the divide while God, or the gods, remain elsewhere. From the Jewish and early Christian perspective, such a division has already given in to one version of the paganism which both were determined to resist.

One final element of our modern world which has militated against imagining the kingdom in our reading of the gospels, and much else besides, is the triumph of left-brain thinking over right-brain thinking which has been massively and memorably set out by Iain McGilchrist in his breathtaking book The Master and his Emissary. ${ }^{28}$ McGilchrist has been attacked from within his own field (he is both a brain scientist and a literary critic, and as such has a unique perspective on the history of ideas). His careful and detailed exposition of the way in which the left and right hemispheres of the human brain function will, no doubt, be modified as research progresses. ${ }^{29}$ But as I read his account of the way in which, in the last three centuries, the left-brain activities of analysing, calculating and organising have steadily taken charge of our world, squeezing out the right-brain activities of imagination, storytelling, and intuitive thinking, I find it uncannily accurate as a description of our world in general and of biblical scholarship in particular. And McGilchrist argues strongly on the basis of brain science itself that our human brains are designed to work in a two-way movement: from the right brain with its initial

27 This position is implicit, and sometimes explicit, in some of the work of Richard A. Horsley, e.g. Paul and Empire: Religion and Power in Roman Imperial Society (Harrisburg, PA: Trinity Press International, 1997; (ed.), Paul and Politics: Ekklesia, Israel, Imperium, Interpretation. Essays in Honor of Krister Stendahl (Harrisburg, PA: Trinity Press International, 2000).

28 The Master and his Emissary: The Divided Brain and the Making of the Western World (New Haven and London: Yale University Press, 2009).

29 Cf. e.g. Grégor Borst, William M. Thompson and Stephen L. Kosslyn, 'Understanding the Dorsal and Ventral Systems of the Human Cerebral Cortex: Beyond Dichotomies', American Psychologist 66/7 (Oct. 2011), pp. 624-32. I am grateful to Prof. Malcolm Jeeves for this and other references and for important discussion on this subject. 
intuitions, to the left brain which works on the detail, and back to the right brain to implement. The right brain is thus the 'master', and the left brain the 'emissary', working at its best within the framework given by the right and intending to pass the results back across. But, as with some observable pathologies (not least schizophrenia), the left brain has taken over, and we have (says McGilchrist) a world in which the master has been betrayed.

McGilchrist is not trying to talk about the world of biblical scholarship, but the following paragraph jumped out at me as a pretty accurate summary of how the discipline has often gone:

We could expect that there would be a loss of the broader picture, and a substitution of a more narrowly focussed, restricted, but detailed, view of the world, making it perhaps difficult to maintain a coherent overview ... This in turn would promote the substitution of information, and information gathering, for knowledge, which comes through experience ... One would expect the left hemisphere to keep doing refining experiments on detail, at which it is exceedingly proficient, but to be correspondingly blind to what is not clear or certain, or cannot be brought into focus right in the middle of the visual field. In fact one would expect a sort of dismissive attitude to anything outside of its limited focus, because the right hemisphere's take on the whole picture would simply not be available to it. ${ }^{30}$

I recognise this picture. Having worked for the Church of England for nearly twenty years, I recognise it as an account of what has happened, damagingly, to our institutions. Whether it has happened in the universities too, in the years I have been absent, I couldn't possibly say. My point is that this has manifestly happened in biblical studies, and especially in New Testament studies, and not least in the study of the gospels. All too often the microscopic analysis of details, vital though it is in its place, has been made to seem an end in itself. 'Objective facts' are all the rage, and whether you're a left-wing hunter of objectivity, determined to disprove the gospels, or a right-wing hunter, determined to show that they are after all 'factual', you may still be missing the point and losing the plot. Facts are left-brain business; vital in their place, but only part of the whole.

Thus, on the one hand, those who presently trumpet the need for a purely and exclusively 'secular' study of the Bible are simply following through the anti-metaphorical agenda of the French Revolution. ${ }^{31}$ Meanwhile, those who respond with an attempted rationalistic proof of, say, Jesus' divinity are often

30 McGilchrist, The Master and his Emissary, pp. 428-9.

31 So McGilchrist, The Master and his Emissary, p. 347. 
themselves remaining within the same sterile antithesis. Like Marxism and capitalism, secularism and fundamentalism are simply the left and right boots of Enlightenment Epicureanism. Only when the detailed left-brain analysis can be relocated as the emissary to the right-wing intuition, with its rich world of metaphor, narrative and above all imagination, can the discipline become healthy again.

The good news is that the gospels themselves resist the destructive, atomising, Epicurean left-brain analysis on its own. They go on telling the story of 'how God became King', and demanding that serious readers learn to imagine a world in which that might be the case, a world reshaped around their account of Jesus. Perhaps, after all, biblical studies might be one place where the return of the Master, a theme indeed made famous by some of Jesus' own stories, might begin to take place. This is a challenge, particularly, for those engaged in doctoral studies. It is much easier to do a purely leftbrain doctorate, and there is still plenty of room for that. But we also need, and quite urgently, a new generation who won't be afraid to see the bigger picture and, without in the least going slack on the necessary left-brain analytic and philological exactitude, come back and articulate a new, freshly imagined vision of the kingdom of God.

\section{Early Christian mission and theology}

All this leads to my concluding remarks on early Christian mission and theology. For over a century now it has been commonplace within the discipline called New Testament studies to assume that the early church had to jettison its Jewishness in order to be relevant to the Gentile world into which it quickly went. Thus, as we saw earlier, it has been assumed that Paul had to downplay the idea of Jesus as Israel's Messiah and to switch, instead, to the more readily available category of the kúpios, the 'Lord'. But this proposal, hugely influential though it has been, simply fails to imagine what 'the kingdom of God' meant to the early Christians, Paul included. ${ }^{32}$ Paul, in fact, held firmly to the ancient Jewish belief, rooted in the Psalms, in Isaiah and in Daniel, that a world ruler would indeed arise from Judaea, that Israel's God would thereby return to dwell amongst and within his people, and that through this the long-awaited new creation of peace and justice would be inaugurated for the whole world. All of that standard Jewish expectation came to fresh flowering in his thought and writing. Of course, the communities which Paul founded were determinedly non-ethnic in their basis. But this

32 Paul does not, of course, use the phrase often; but when he does it is clear that it remains at the centre of his worldview. Cf. e.g. Rom 14:17; 1 Cor 4:20, 6:9. (Full list in Wright, Jesus and the Victory of God, p. 668.) 
was not because Paul had as it were gone soft on the essential Jewishness of his mission, or because there was something wrong (as Epicureans imagine) with Judaism, but because he believed that it was precisely part of the age-old divine plan that when God did for Israel what he was going to do for Israel then the nations would be brought under the healing, saving rule of this one

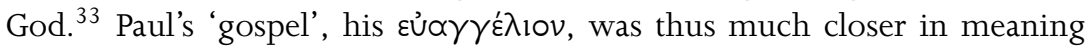
to the various $\varepsilon \dot{u} \propto \gamma \gamma^{\prime} \hat{\lambda}_{1} \propto$ of Caesar than most of modern scholarship has imagined. It was, as Acts 17 (already quoted) indicates, the royal announcement, right under Caesar's nose, that there was 'another king, namely Jesus'. And Paul believed that this royal announcement, like that of Caesar, was not a take-it-or-leave-it affair. It was a powerful summons through which the living God worked by his Spirit in hearts and minds, to transform human character and motivation, producing the tell-tale signs of faith, hope and love which Paul regarded as the biblically prophesied marks of God's true people.

The communities which sprang into surprised existence as Paul went around making this royal announcement were remarkably devoid of an obvious symbolic world. They were precisely not defined by the worldviewsymbols of Judaism - Temple, Torah observance and so on. They certainly didn't adopt the symbols of the surrounding pagan culture. How could this new community, this new sort of community, retain what for Paul was its vital centre, namely its strong unity across traditional social divisions, and its strong holiness in matters of those perennial categories of human life, money, sex and power? For Paul the answer was simple. The community needed to understand what it was that had happened in Jesus the Messiah, and in particular who the God was into whose new world they had been brought. What we see in Paul is thus properly characterised as the birth of the discipline which later came to be called Christian theology, by which I mean the prayerful and scripture-based reflection, from within the common life of the otherwise disparate body called the church, on who exactly the one God was and what his action in Jesus and by the Spirit was to mean. Early Christian theology was not an exercise undertaken for the sake of speculative system-building. It was load-bearing. If the unity and holiness of the early church were the central symbols of the movement, they could only be held in place if a vigorous theology was there to stabilise them in the winds and storms of the first century. Theology, in this sense, serves ecclesiology and thus the kingdom-based mission. Actually, I have come to worry about a post-Enlightenment theology which doesn't do this, that thinks the point is

33 This is why, in my view, Barclay's picture of Paul as presenting a puzzle gets off on the wrong foot: see John M. G. Barclay, Jews in the Mediterranean Diaspora: From Alexander to Trajan (323 BCE-117 CE) (Edinburgh: T\&T Clark, 1996), ch. 13. 
simply to 'prove' the divinity of Jesus, or his resurrection, or the saving nature of his death in themselves, thereby demonstrating fidelity to the Creeds or some other regula fidei. In the gospels themselves it isn't like this. All these things matter, but they matter because this is how God is becoming king. To prove the great Creeds true, and to affirm them as such, can sadly be a diversionary exercise, designed to avoid the real challenge of the first-century gospel, the challenge of God's becoming king in and through Jesus.

This challenge, of course, required imagination: not the undisciplined fantasy of which left-brain thinking often accuses right-brain thinking, but the imaginative leap into a new worldview, significantly different from the worldviews of paganism, with their many gods who might either be far removed, as in Epicureanism, or rolled into one and close at hand, as in Stoicism - and indeed from the worldviews of ancient Judaism, with their fierce concentration on the symbols of land, nation, Temple and Torah. But the leap was not made into the unknown. The imaginative leap required was made on the basis of Jesus, Jesus the crucified and risen Jewish Messiah, Jesus the one in and through whom Israel's God had at last returned in person to rescue his people and the world. And to sustain precisely that leap, the early Christians told and retold, and eventually wrote down, the story of Jesus, not of course as 'neutral' reportage (there is no such thing) but as the story of what the one God had done and how he had done it.

The four gospels, then, to return to our starting point, are thus appropriately named 'gospel', in line both with Isaiah 40 and 52 and with the contemporary pagan usage. ${ }^{34}$ They themselves, in telling the story of how God became king in and through Jesus, invite their readers to the imaginative leap of saying, 'Suppose this is how God has done it? Suppose the world's way of empire is all wrong? Suppose there's a different way, and suppose that Jesus, in his life, death and resurrection, has brought it about?' And the gospels themselves, of course, contain stories at a second level, stories purportedly told by Jesus himself, which were themselves, in their day, designed to break open the worldview of their hearers and to initiate a massive imaginative leap to which Jesus gave the name 'faith'. The gospels invite their readers, in other words, to a multiple exercise, both of imagining what it might have been like to make that leap in the first century and, as a second stage, of imagining what it might be like to do so in one's own day. For too long gospel study has been dominated by the attempt to make the gospels reflect, simply, the faith-world of the early church;

${ }^{34}$ Isa 40:9; 52:7. The contemporary pagan usage is now widely discussed; see e.g. Graham N. Stanton, Jesus and Gospel (Cambridge: Cambridge University Press, 2004), ch. 2. 
why, after all, would the early Christians have been particularly interested in miscellaneous stories of what Jesus actually said or did, when all that really mattered was his saving death, making the gospels simply 'passion narratives with extended introductions'? The conservative response has been that early converts would naturally want to know more about this Jesus in whom they had come to place their faith. But this stand-off, on both sides, has usually failed to reflect the larger question: that the gospels tell the story of Jesus not out of mere historical anecdotage or faith-projection, but because this is how Jesus launched the kingdom of God, which he then accomplished in his death and resurrection. Even to hold this possibility in one's head requires, in today's Western church, whether radical or conservative, no less than in the non-Christian world, a huge effort of the imagination.

This imagination, like all good right-brain activity, must then be firmly and thoroughly worked through the left brain, disciplined by the rigorous historical and textual analysis for which the discipline of biblical studies has rightly become famous. But by itself the left brain will produce, and has often produced, a discipline full of facts but without meaning, high on analysis and low on reconstruction, good at categories and weak on the kingdom. The task before us - challenging, to be sure, but also richly rewarding - is that of imagining the kingdom in a way that will simultaneously advance the academic understanding of our extraordinary primary texts and enrich the mission and theology of tomorrow's church. It is, after all, just as difficult today as it was in the first century to imagine what the kingdom of God might look like. Rigorous historical study of the gospels and the other early Christian writings has a proper role to play in fuelling, sustaining and directing that imagination, and in helping to translate it into reality. 